\title{
Transcriptional regulation of the grape cytochrome P450 monooxygenase gene CYP736B expression in response to Xylella fastidiosa infection
}

\author{
Davis W Cheng 1,2, Hong Lin*1, Yuri Takahashi3,4, M Andrew Walker ${ }^{3}$, Edwin L Civerolo ${ }^{1}$ and Drake C Stenger ${ }^{1}$
}

\begin{abstract}
Background: Plant cytochrome P450 monooxygenases (CYP) mediate synthesis and metabolism of many physiologically important primary and secondary compounds that are related to plant defense against a range of pathogenic microbes and insects. To determine if cytochrome P450 monooxygenases are involved in defense response to Xylella fastidiosa $(X f)$ infection, we investigated expression and regulatory mechanisms of the cytochrome P450 monooxygenase CYP736B gene in both disease resistant and susceptible grapevines.

Results: Cloning of genomic DNA and CDNA revealed that the CYP736B gene was composed of two exons and one intron with GT as a donor site and AG as an acceptor site. CYP736B transcript was up-regulated in PD-resistant plants and down-regulated in PD-susceptible plants 6 weeks after $X$ inoculation. However, CYP736B expression was very low in stem tissues at all evaluated time points. 5'RACE and 3'RACE sequence analyses revealed that there were three candidate transcription start sites (TSS) in the upstream region and three candidate polyadenylation (PolyA) sites in the downstream region of CYP736B. Usage frequencies of each transcription initiation site and each polyadenylation site varied depending on plant genotype, developmental stage, tissue, and treatment. These results demonstrate that expression of CYP736B is regulated developmentally and in response to Xfinfection at both transcriptional and posttranscriptional levels. Multiple transcription start and polyadenylation sites contribute to regulation of CYP736B expression.
\end{abstract}

Conclusions: This report provides evidence that the cytochrome P450 monooxygenase CYP736B gene is involved in defense response at a specific stage of $X f$ infection in grapevines; multiple transcription initiation and polyadenylation sites exist for CYP736B in grapevine; and coordinative and selective use of transcription initiation and polyadenylation sites play an important role in regulation of CYP736B expression during growth, development and response to Xf infection.

\section{Background}

Plant cytochrome P450 monooxygenases are a group of redox proteins that catalyze various oxidative reactions [1]. It is proposed that cytochrome P450 monooxygenases mediate synthesis and metabolism of many physiologically important compounds. Steroids, fatty acids, lignins, terpenes, alkaloids, phenylpropanoids, and phytoalexins are examples of these primary and secondary compounds that act as plant defense agents against a range of diverse pathogenic microbes and insect pests [2-

*Correspondence: hong.lin@ars.usda.gov

1 San Joaquin Valley Agricultural Science Center, USDA-ARS 9611 South Riverbend Avenue, Parlier, CA 93648, USA

Full list of author information is available at the end of the article
4]. Cytochrome P450 enzymes are also involved in several biosynthesis pathways in leaf tissues of Arabidopsis and function as part of the highly sophisticated network of plant defense reactions [5]. These defense responses include the hypersensitive response [6] and inhibition of growth of particular plant pathogens [7]. Gene expression analysis has revealed that most cytochrome P450 genes are strictly regulated in response to phytohormones (salicylic acid, jasmonic acid, ethylene and abscisic acid), pathogens (necrotrophic fungal pathogens Alternaria alternata and $A$. brassicicola), UV damage, heavy metal toxicity, mechanical injury, drought, high salinity and low temperatures [8]. Therefore, cytochrome $\mathrm{P} 450$ genes may be involved in plant defense responses to abiotic and 
biotic stresses. How cytochrome $\mathrm{P} 450$ genes are regulated in response to these stresses, especially to bacterial infection, is not understood.

The most widely cultivated grape species is Vitis vinifera. These grapevines are highly susceptible to many pests and pathogens, including Xylella fastidiosa (Xf), the bacterium responsible for Pierce's disease (PD). $X f$ is transmitted by xylem-feeding sharpshooters. PD has been an important but localized disease in California for over 100 years. Recently, the introduction of the glassywinged sharpshooter vector into California resulted in new and range expanding epidemics of PD [9]. PD susceptible grapevines infected with $X f$ exhibit inhibited periderm development in stems (green islands), leaf blade separation from the petiole (matchsticks), irregular leaf scorching, fruit cluster dehydration, stunting and eventual plant death [10-12]. While cultivars of $V$. vinefera are susceptible to $\mathrm{PD}$, several species of grapevine are resistant. A breeding program based on resistance from $\mathrm{V}$. arizonica has been developed and led to genetic mapping of a single locus for resistance $(P d R 1)$ in the 9621 population $[11,13]$. This population is a cross of two half-sib genotypes, D8909-15 ( $V$. rupestris 'A. de Serres $\times V$. arizonica b42-26) $\times$ F8909-17 (V. rupestris 'A. de Serres' $\times V$. arizonica/candicans b43-17) [13]. Two progeny from this population, one resistant (9621-67) and the other susceptible (9621-94), were characterized for transcriptomic profiles [14], which implicated involvement of cytochrome $\mathrm{P} 450$ genes in a defense response to $X f$ infection http://cropdisease.ars.usda.gov/vitis at/main-page.htm.

To further characterize how cytochrome P450 monooxygenase genes are regulated in response to $X f$ infection, the genotypes 9621-67 and 9621-94 were used to study temporal and spatial expression and transcriptional regulation in inoculated greenhouse-grown plants. This report characterizes the structure, expression and transcript maturation of a cytochrome P450 monooxygenase encoded by the CYP736 gene.

\section{Results \\ Genomic organization and structure of CYP736 genes in grape}

Genomic DNA sequences of grape cytochrome P450 monooxygenase genes cloned from PD- resistant and susceptible grapevines using the PCR primer P450F1 and P450R1 (Table 1) were 2,927 bp (Accession FJ620897) and 2,892 bp (Accession FJ620898), respectively. The cDNA sequences of grape cytochrome $\mathrm{P} 450$ monooxygenase genes cloned from leaf tissues of control PD-resistant and -susceptible grapevines using the PCR primers P450F1 and P450R1 (Table 1) were 1488 bp (Accessions FJ828517 and FJ828518). BLAST analysis of grapevine genomic DNA sequences revealed that the grape P450 monooxygenase gene has three homologous copies (CYP736A,
CYP736B and CYP736C) in tandem on grape chromosome 7 (Figure 1). These three copies share 89\%, 98\% and $78 \%$ nucleotide sequence identity, respectively, compared to the closest grape genomic DNA contig sequence (Accession AM475392.1). The grape P450 monooxygenase genes we cloned from PD-resistant and susceptible grapevines were CYP736B genes that shared 93.6\%, 99\%, 98.6\%, 90.3\% genomic DNA sequence identity with each other in the $5^{\prime}$ untranslated, exon, intron, and 3' untranslated regions (UTR), respectively. The grape $\mathrm{P} 450$ monooxygenase CYP736B genes cloned from PD- resistant and -susceptible grapevines have the same structure. Main features of these two CYP736B genes are: two exons, one intron with GT as 5'splice site and AG as 3' splice site. Compared to the CYP736B gene sequence from the PD-resistant grapevine, there are three $C$ to $T$ substitutions and one insertion (CTAT) in the upstream UTR region (1000 bp), one $A$ to $G$ and one $T$ to $C$ substitution in the exon 1 region, one $\mathrm{G}$ to $\mathrm{A}$, one $\mathrm{T}$ to $\mathrm{G}$ and one $\mathrm{C}$ to $\mathrm{G}$ substitution in the intron region, one $\mathrm{C}$ to $\mathrm{A}$, one $\mathrm{A}$ to $\mathrm{C}$, one $\mathrm{C}$ to $\mathrm{T}$, and one $\mathrm{T}$ to $\mathrm{C}$ substitution and a large deletion (39 bp) in the downstream non-coding region (300 bp) of the CYP736B gene from the PD-susceptible grapevine. DNA motif analysis indicated that there are nine major transcriptional regulatory motifs in the upstream non-coding region of the CYP736B gene, including one TATA box, five CAAT box, one I box, one G box, and one W box (Figure 2).

\section{Temporal and spatial expression of CYP736B genes in grape}

Expression of CYP736B in stem and leaf tissues of both PD-resistant and -susceptible grapevines was detected at different stages of growth and disease development in response to $X f$ infection using a pair of specific primers P450F1 and P450R1 (Table1) for the CYP736B coding region. Quantitative Real-time PCR analysis results showed that expression of CYP736B was much higher in leaf tissues than in stem tissues of both PD-resistant and susceptible grapevines, ranging from $30-138.6$ fold greater depending on growth stage (Table 2). In stem tissues of control PD-resistant plants, CYP736B expression at weeks 1 and 10 was similar but slightly lower at week 6 when expression of $C Y P 736 B$ was elevated by a factor of 1.3 ( $\mathrm{p}<0.05)$. In contrast, expression of $C Y P 736 B$ was increased by factors of $5.3(\mathrm{p}<0.01)$ and $2.9(\mathrm{p}<0.01)$ in stem tissues of the control PD-susceptible grapevine at week 6 and week 10. However, $X f$ infection did not result in a significant change in CYP736B expression in stem tissues of the PD-susceptible grapevine at week 1 . Infection did cause a significant decrease of CYP736B expression in stem tissues of PD-susceptible grapevine to 4.08fold less $(\mathrm{p}<0.01)$ and 1.71 -fold less $(\mathrm{p}<0.05)$ at weeks 6 and 10, respectively. Interestingly, $C Y P 736 B$ expression 
Table 1: PCR Primers used in this study

\begin{tabular}{|c|c|c|}
\hline Name & Sequences (5' - 3') & Comments \\
\hline P450F1 & TGAAAATTAACCAGCCACCAT & Gene and cDNA cloning \\
\hline P450R1 & TTATATCATTTGTGAAAGC GACAAG & Gene and CDNA cloning \\
\hline P450F2 & TGCATGGACTGATGCAGAC & Expression detection in gel \\
\hline P450R2 & СТССТСАТTCATGTCCAACTC & Expression detection in gel \\
\hline P450F3 & TGGAGTTGCTCAGCAGCCATA & Internal primer for DNA sequencing \\
\hline P450R3 & TATATGGAA GCCATCGACTGTG & Internal primer for DNA sequencing \\
\hline 5'UTRF1 & TGCAGCTTCATATCTTGGGTITTCTC & 5'UTR cloning (1000 bp) \\
\hline 5'UTRR3 & GGTGGCTGGTT AATTTTCAGTATTCAG & 5'UTR cloning (1000 bp) \\
\hline 3'UTRF1 & ATATAATCTCTGTATCATTGCCAACTGAG & 3'UTR cloning (600 bp) \\
\hline 3'UTRR1 & ATGCTAAACATCAAATCGAATACTCTCA & 3'UTR cloning (600 bp) \\
\hline SYBR-P450F1 & TGCATGGACTGATGCAGAC & Real-time qPCR for gene expression \\
\hline SYBR-P450R1 & СТССТСАТTСАTGTCCAACTC & Real-time qPCR for gene expression \\
\hline SYBR-P450F2 & CCAACATCAAAGCTATATCTTTG & Real-time qPCR for pre-mRNA splicing \\
\hline SYBR-P450R2 & TGGAGGCTGCCATCAT ATC & Real-time qPCR for pre-mRNA splicing \\
\hline P450-5'RACE GSP2 & CGATACTITTTGGATAGAGCTTGTAGAGC & First 5'RACE \\
\hline P450-5'RACE GSP3 & CGACAAGCTCCCTAACATATGCATATT & Second 5'RACE \\
\hline P450-3'RACE GSP1 & CGAGCAACTTGTTCATTGCTTTGAT & First 3'RACE \\
\hline P450-3'RACE GSP2 & CGAAGA TAACATGTTGGCAAGTGAGTT & Second 3'RACE \\
\hline SYBR-P450B 5'UTRF1 & ACTGACTTCTAGTTTAAATTTTTCTT & Real-time qPCR for 5'RACE \\
\hline SYBR-P450B 5'UTRR1 & TGGCTGGTTAATTTTCAGTATT & Real-time qPCR for 5'RACE \\
\hline SYBR-P450B 3'UTRF1 & ATATAATCTCTGTATC ATTGCCAA & Real-time qPCR for 3'RACE \\
\hline SYBR-P450B 3'UTRR1 & ACTACCAGATGAAAATCATTAAAT & Real-time qPCR for 3'RACE \\
\hline P450-5'RACE GSP3 & CGACAAGCTCCCTAACATATGCATATT & 5 ' primer extension \\
\hline P450-3'RACE GSP2 & CGAAGA TAACATGTTGGCAAGTGAGTT & 3' primer extension \\
\hline$-300 U F$ & AGTCATATATGACTTAGCAAGAGAACTCCAC & PCR for pre-mRNA splicing at -300 TSS \\
\hline$-140 \mathrm{UF}$ & AACCGCACCTTATC СТCTTCACAA & PCR for pre-mRNA splicing at -140 TSS \\
\hline$-60 U F$ & TGAAACCACCCAAGAACTTCAAAAC & PCR for pre-mRNA splicing at -60 TSS \\
\hline$++70 \mathrm{UR}$ & CATAAAGCATAAAGCGTTATTATTCATATTT & PCR for pre-mRNA splicing at ++70 poly(A) site \\
\hline$++200 \mathrm{UR}$ & СTAAGTTCCATATTCT TCCTTCTTAAGTTCA & PCR for pre-mRNA splicing at ++200 poly $(A)$ site \\
\hline$++260 \mathrm{UR}$ & ACTCAGAACTAAGTITTATTTCACTTGATCAA & PCR for pre-mRNA splicing at ++260 poly $(A)$ site \\
\hline
\end{tabular}

was elevated up to 112.9-fold and 74.9-fold in leaf tissues relative to stem tissues of both control PD-resistant and susceptible grapevines at week 1 post-inoculation, respectively, but down-regulated in leaf tissues with progression of plant growth under normal conditions without $X f$ infection. For example, $C Y P 736 B$ expression was decreased by 1.31 -fold ( $\mathrm{p}<0.01$ ) and 2.29-fold $(\mathrm{p}<0.01$ ) at weeks 6 and 10 in leaf tissues of the PD-resistant grapevine, whereas $C Y P 736 B$ expression decreased by 1.79 fold $(\mathrm{p}<0.01)$ and 2.53 -fold $(\mathrm{p}<0.01)$ at weeks 6 and 10 in leaf tissues of the PD-susceptible grapevine. However, $X f$ infection resulted in increase of $C Y P 736 B$ expression up to 1.6-fold $(\mathrm{P}<0.01)$ in leaf tissues of the $\mathrm{PD}$-resistant grapevine and a decrease of $C Y P 736 B$ expression by 2.11 fold $(\mathrm{P}<0.01)$ in leaf tissues of the $\mathrm{PD}$-susceptible grapevine.

The cDNA sequences of $C Y P 736 B$ transcripts from leaf samples of both PD-resistant and -susceptible genotypes with or without $X f$ infection were determined. The results indicated that amino acid sequences encoded by CYP736B transcripts were highly similar (99\% identical) within each PD-resistant and-susceptible sampling group and between the two groups, suggesting that involvement of $C Y P 736 B$ in the defense response against $X f$ infection could be regulated at transcriptional and posttranscriptional levels. 


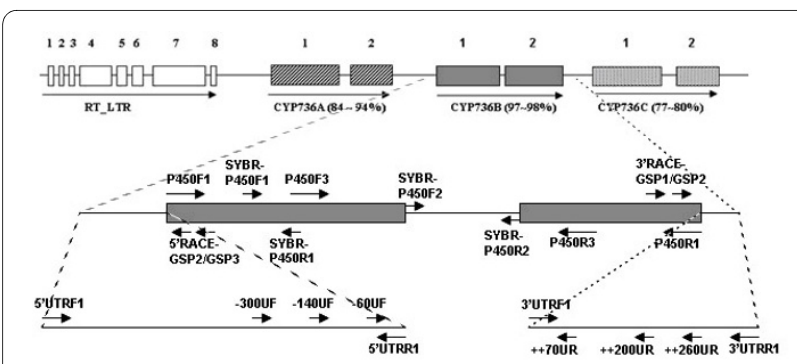

Figure 1 Genomic organization and structure of cytochrome P450 CYP736 genes in grapevines. There are three cytochrome P450 genes, CYP736A, CYP736B and CYP736C, flanked on the left with a RELTR gene on grape chromosome 7. Numbers on the top indicate order of exons, and the arrow indicates direction of transcription. Exon size and distance between genes and exons were drawn to approximate scale. The DNA coding sequence identity of each CYP736gene derived from a large genomic contig CU459237.1 (4,713,370 bp) was compared with the target CYP736B gene cloned from PD- resistant 9621-67 grape selection and is shown below each gene member. The directions of PCR primers are shown in arrows at specific locations.

\section{Pre-mRNA splicing patterns of CYP736B genes}

The cDNA sequences of $C Y P 736 B$ transcripts from leaf and stem tissue of both PD-resistant and -susceptible grapevines at different stages of growth and development with or without $X f$ infection were cloned using $C Y P 736 B$ coding region specific primers P450F1 and P450R1. These cDNA sequences were further examined to determine if gene structure and/or posttranscriptional processing patterns changed over time and tissues. The results showed that $C Y P 736 B$ transcripts were spliced with $G \mathrm{~T}$ as a donor site and AG as an acceptor site within the intron sequence of $C Y P 736 B$ pre-mRNAs in both PDresistant and -susceptible samples (Figure 2). To study the dynamic pattern of pre-mRNA splicing of $C Y P 736 B$, we designed a pair of Real-time PCR primers, SYBR-P450F2 and SYBR-P450R2 (Table 1), for quantitative analysis of the relative frequency of unspliced $C Y P 736 B$ transcripts in leaf tissues during growth and development in response to $X f$ infection. As shown in Table 3, the relative frequency of unspliced $C Y P 736 B$ transcripts was 3 to 4fold less in leaf tissues of control PD-resistant and -susceptible grapevines at week 1 when genomic DNA was used as a control reference for Real-time Q-PCR analysis. The results indicate that most $C Y P 736 B$ pre-mRNA transcripts were correctly spliced in leaf tissues of both control PD-resistant and -susceptible grapevines at week 1 in plants not inoculated with $X f$. In comparison, relative frequency of unspliced $C Y P 736 B$ transcripts was significantly increased up to 16.22 - and 4.51-fold greater in leaf tissues of control PD- resistant plants at week 6 and 10, respectively. In contrast, relative frequency of unspliced CYP736B transcripts was as low as 1.18 - and 2.21-fold less in leaf tissues of control PD-susceptible plants at week 6 and 10, respectively. However, when the leaf tis-

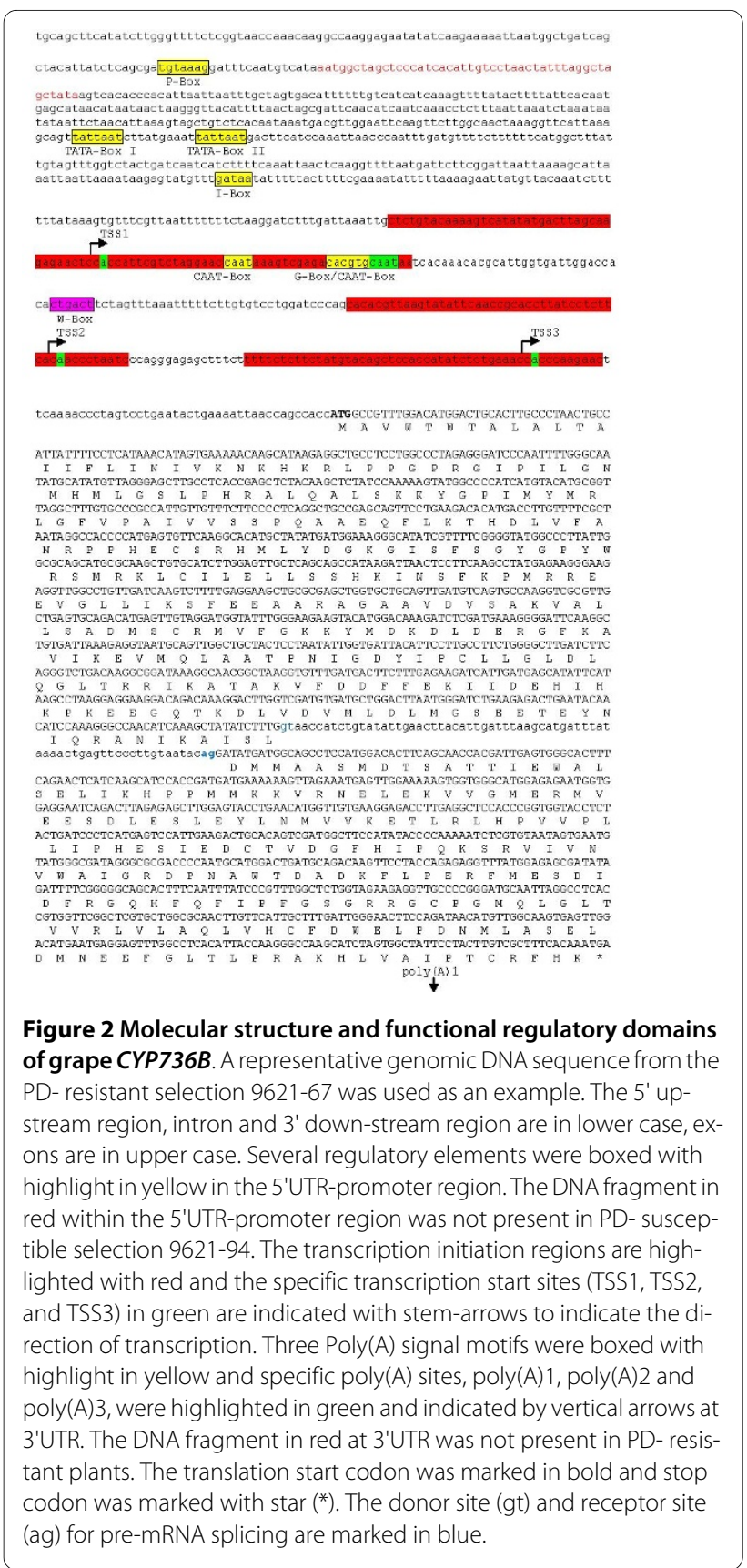

sues of the PD- resistant grapevines was inoculated the relative frequency of unspliced $C Y P 736 B$ transcripts decreased to as low as 1.79 - and 1.95-fold at week 1 and 6 and then increased to 3.59-fold greater at week 10. However, when leaf tissues of the PD- susceptible grapevines were inoculated, the relative frequency of unspliced CYP736B transcripts increased to 2.73- and 358.95-fold greater at week 1 and 6 , respectively, and then decreased to 1.23-fold less at week 10. Representative cDNA sequencing confirmed that both spliced and unspliced CYP736B transcripts were generated in both PD-resistant 
Table 2: Quantitative analyses of CYP736B gene expression in stem and leaf tissues of grapevines at different stages of growth (1week, 6 week and 10 week after inoculation) with Xf infection (T) and without Xf infection (C)

\begin{tabular}{|c|c|c|c|c|c|c|}
\hline \multirow[t]{2}{*}{ Tissue } & \multirow[t]{2}{*}{ Genotype } & \multirow[t]{2}{*}{ Growth Stage } & \multirow[t]{2}{*}{ Treatment } & \multirow{2}{*}{$\begin{array}{c}\text { Relative Expression } \\
\text { Level (SD) }\end{array}$} & \multirow{2}{*}{$\begin{array}{c}\text { Fold Difference in Expression } \\
\text { Relative Folds for } \\
\text { Growth Stages ( } p \text { value) }\end{array}$} & \multirow{2}{*}{$\begin{array}{c}\text { Fold Difference in } \\
\text { Expression } \\
X f \text { Infection ( } p \text { value) }\end{array}$} \\
\hline & & & & & & \\
\hline \multirow[t]{12}{*}{ Stems } & $9621-67$ & $1 \mathrm{~W}$ & $C$ & 1 (reference) & 1.00 (reference) & \\
\hline & & & $\mathrm{T}$ & $1.5(0.56)$ & & $1.50(0.02348)$ \\
\hline & & $6 \mathrm{~W}$ & $\mathrm{C}$ & $1.3(0.26)$ & $1.30(0.01938)$ & \\
\hline & & & $\mathrm{T}$ & $2.5(1.00)$ & & $1.92(0.00797)$ \\
\hline & & $10 \mathrm{~W}$ & $C$ & $0.8(0.31)$ & $0.80(0.06844)$ & \\
\hline & & & $\mathrm{T}$ & $0.4(0.26)$ & & $-2.00(0.02928)$ \\
\hline & $9621-94$ & $1 \mathrm{~W}$ & $C$ & $1.1(0.26)$ & $1.1(0.239829)$ & \\
\hline & & & $\mathrm{T}$ & $1.2(0.41)$ & & $1.09(0.26111)$ \\
\hline & & $6 \mathrm{~W}$ & $C$ & $5.3(1.26)$ & $5.30(0.00000)$ & \\
\hline & & & $\mathrm{T}$ & $1.3(0.37)$ & & $-4.08(0.00001)$ \\
\hline & & $10 \mathrm{~W}$ & C & $2.9(0.98)$ & $2.90(0.00038)$ & \\
\hline & & & $\mathrm{T}$ & $1.7(0.55)$ & & $-1.71(0.01387)$ \\
\hline \multirow[t]{12}{*}{ Leaves } & $9621-67$ & $1 \mathrm{~W}$ & $\mathrm{C}$ & $112.9(19.56)$ & 1.00 (reference) & \\
\hline & & & $\mathrm{T}$ & $94.8(16.41)$ & & $-1.19(0.05631)$ \\
\hline & & $6 \mathrm{~W}$ & C & $86.4(10.97)$ & $-1.31(0.00794)$ & \\
\hline & & & $\mathrm{T}$ & $138.6(6.1)$ & & $1.60(0.00000)$ \\
\hline & & $10 \mathrm{~W}$ & $C$ & $49.4(15.43)$ & $-2.29(0.00005)$ & \\
\hline & & & $\mathrm{T}$ & $41(14.26)$ & & $-1.20(0.17655)$ \\
\hline & $9621-94$ & $1 \mathrm{~W}$ & C & $74.9(11.46)$ & $-1.51(0.00107)$ & \\
\hline & & & $\mathrm{T}$ & $70.2(16.71)$ & & $-1.07(0.28799)$ \\
\hline & & $6 \mathrm{~W}$ & C & $63.2(10.77)$ & $-1.79(0.00014)$ & \\
\hline & & & $\mathrm{T}$ & $30(10.93)$ & & $-2.11(0.00017)$ \\
\hline & & $10 \mathrm{~W}$ & $C$ & $44.6(10.79)$ & $-2.53(0.00001)$ & \\
\hline & & & $\mathrm{T}$ & $40.9(6.14)$ & & $-1.09(0.24242)$ \\
\hline
\end{tabular}

and -susceptible grapevines irrespective of $X f$ infection (data not shown).

\section{Determination of candidate 5 ' termini of grape CYP736B transcripts}

Due to lower levels of $C Y P 736 B$ expression in stem tissues at all growth stages analyzed and the most significant change of $C Y P 736 B$ gene expression in leaf tissues at week 6 , the 5 'RACE method was used to determine transcription initiation sites in leaf tissues of both PD-resistant and -susceptible grapevines at week 1 and 6 under inoculated and uninoculated conditions. As shown in Figure 3a, there were 1 - 3 major cDNA bands generated from leaf RNA templates from both PD-resistant and - susceptible grapevines at week 1 and week 6 , with or without $X f$ inoculation. To elucidate the nature of these major multiple 5'RACE cDNA bands, we combined promoter and transcription start site prediction and experimental verification methods. Bioinformatics-aided promoter prediction revealed that there were potentially three major transcription start sites (Figure 2): TSS1 (290 to -240$)$, TSS2 (-136 to -86$)$, and TSS3 (-69 to -19$)$. 5 'RACE cDNA cloning and sequencing analysis revealed that all of predicted transcription start sites were found in CYP736B transcripts as we predicted from the agarose gel analysis of the 3'RACE-amplified PCR products (Figure 3). We further quantified the relative abundance of major transcription start site usage using Real-time PCR 
Table 3: Relative frequencies of unspliced CYP736B transcripts in leaf tissues of PD-resistant (9621-67) and -susceptible (9621-94) grapevines at different stages of growth (weeks after inoculation) with or without Xf infection

\begin{tabular}{|c|c|c|c|c|c|c|}
\hline \multirow[t]{2}{*}{ Genotype } & \multirow[t]{2}{*}{ Growth Stage } & \multirow[t]{2}{*}{ Treatment } & Unspliced transcripts & \multirow[t]{2}{*}{ SD } & \multirow{2}{*}{$\begin{array}{l}\text { Fold Difference for } \\
\text { Growth Stage } \\
\text { (p value) }\end{array}$} & \multirow{2}{*}{$\begin{array}{l}\text { Fold Difference for } \mathbf{X} \\
\text { Infection } \\
\text { (p value) }\end{array}$} \\
\hline & & & Fold Difference & & & \\
\hline & & & $1.00^{*}$ & 0.00 & & \\
\hline \multirow[t]{6}{*}{$9621-67$} & $1 \mathrm{~W}$ & $\mathrm{C}$ & -3.22 & 0.10 & 1.00 (reference) & \\
\hline & & $\mathrm{T}$ & -5.88 & 0.14 & & $-1.79(0.117687)$ \\
\hline & $6 \mathrm{~W}$ & $\mathrm{C}$ & 5.03 & 1.85 & $16.22(0.005751)$ & \\
\hline & & $\mathrm{T}$ & 2.58 & 0.59 & & $-1.95(0.047095)$ \\
\hline & $10 \mathrm{~W}$ & $\mathrm{C}$ & 1.40 & 0.25 & $4.51(0.001136)$ & \\
\hline & & $\mathrm{T}$ & 5.02 & 1.17 & & $3.59(0.003156)$ \\
\hline \multirow[t]{6}{*}{$9621-94$} & $1 \mathrm{~W}$ & $\mathrm{C}$ & -4.00 & 0.08 & $0.81(0.237776)$ & \\
\hline & & $\mathrm{T}$ & -7.14 & 0.01 & & $2.73(0.033004)$ \\
\hline & $6 \mathrm{~W}$ & $\mathrm{C}$ & -2.70 & 0.03 & $1.18(0.198382)$ & \\
\hline & & $\mathrm{T}$ & 131.30 & 11.21 & & $358.95(0.00002)$ \\
\hline & $10 \mathrm{~W}$ & $\mathrm{C}$ & -1.47 & 0.07 & $2.21(0.002999)$ & \\
\hline & & $\mathrm{T}$ & -1.79 & 0.02 & & $-1.23(0.022641)$ \\
\hline
\end{tabular}

Genomic DNA was used as a reference for unspliced/spliced transcript analysis.

analysis with a pair of primers SYBR-P450F1 and SYBRP450R1. As summarized in Table 4, usage frequency of both TSS2 and TSS3 varied, from 0.66- to 9.20-fold for TSS2 and from 0.35 - to 8.67 -fold for TSS3, respectively,

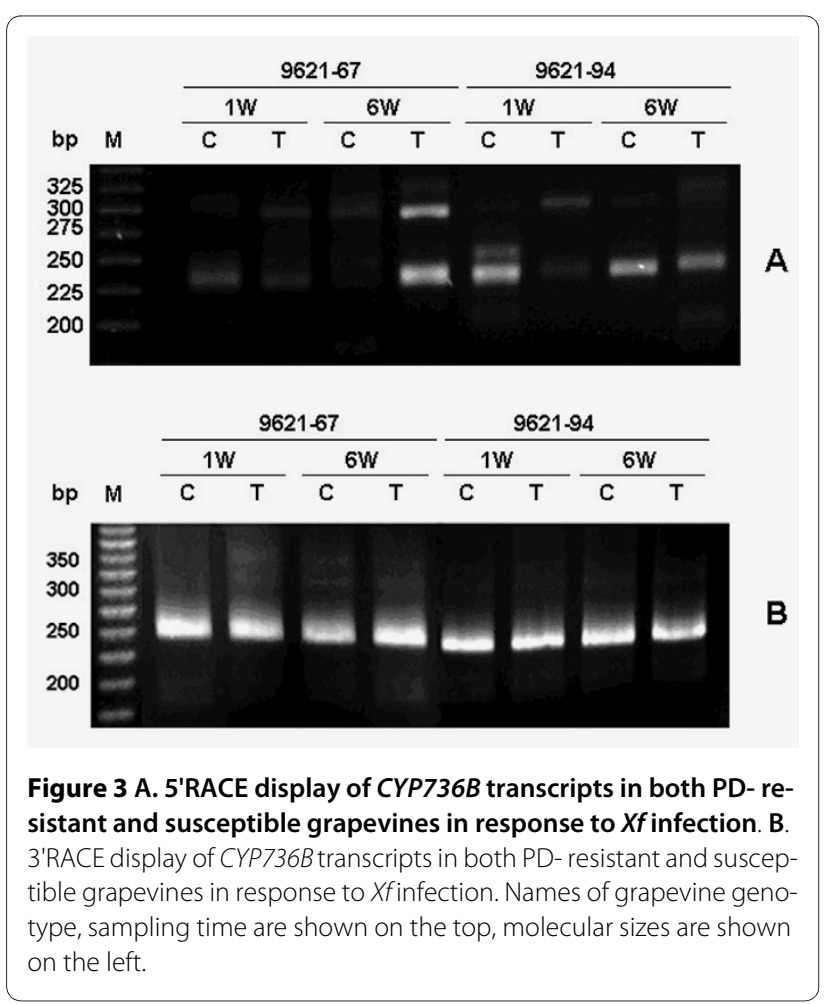

in leaf tissues of both PD -resistant and susceptible grapevines at different stages of growth without $X f$ infection. Compared to control plants, however, usage of TSS2 increased significantly in leaf tissues of resistant plants at week 1 (17.65-fold greater than susceptible control plants, 26.74-fold greater than resistant control plants, $n$ $=3, \mathrm{p}=0.001854)$ and at the growth stage week $6(37.12$ fold greater than susceptible control plants, 4.03-fold greater than resistant control plants, $\mathrm{n}=3, \mathrm{p}=0.017017$ ) after $X f$ inoculation. In contrast, usage frequency of TSS2 increased significantly after $X f$ inoculation at week 1 (2.22-fold greater than control plants, $\mathrm{n}=3, \mathrm{p}=0.003532$ ) in leaf tissues of susceptible plants, but remained unchanged (1.42- and 1.56-fold for control and Xf infected plants, respectively, compared to the susceptible control plant for $X f$ infection at week $1, \mathrm{n}=3, \mathrm{p}=$ 0.354589 ) at week 6 after $X f$ inoculation. Similarly, usage frequency of TSS3 remained unchanged at growth stage week 1 after $X f$ inoculation (0.62- and 0.50-fold, respectively compared to the susceptible control plants, $\mathrm{n}=3, \mathrm{p}$ $=0.204438)$, but greatly increased at the growth stage week 6 after $X f$ inoculation (8.67-fold higher than susceptible control plants, 24.77 fold higher than resistant control plants, $\mathrm{n}=3, \mathrm{p}=0.000483$ ) in leaf tissues of resistant plants. Usage frequencies of TSS3 were low in leaf tissues of susceptible plants at week 1 (0.4-fold compared to control plants, $\mathrm{n}=3, \mathrm{p}=0.000203)$ and week $6(0.23$-fold compared to control plants, $\mathrm{n}=3, \mathrm{p}=0.017818)$ after $X f$ inoculation. 
Table 4: Relative abundance of transcription start site usage in TSS2 and TSS3 regions of CYP736B gene in leaf tissues of both PD-resistant (9621-67) and -susceptible (9621-94) plants after 1 and 6 weeks of inoculation with Xf

\begin{tabular}{|c|c|c|c|c|c|c|c|c|}
\hline \multirow[t]{2}{*}{ Genotype } & \multirow[t]{2}{*}{ Weeks } & \multirow[t]{2}{*}{ Treatment } & \multicolumn{3}{|c|}{ TSS2 } & \multicolumn{3}{|c|}{ TSS3 } \\
\hline & & & $\begin{array}{l}\text { Average } \\
\text { (Fold difference) }\end{array}$ & SD & t-test (p) & $\begin{array}{l}\text { Average } \\
\text { (Fold difference) }\end{array}$ & SD & t-test (p) \\
\hline \multirow[t]{4}{*}{$9621-67$} & 1 & Control & 0.66 & 0.36 & & 0.62 & 0.19 & \\
\hline & & $X f$-Infected & $17.65^{* *}$ & 4.83 & 0.001854 & 0.50 & 0.15 & 0.204438 \\
\hline & 6 & Control & 9.20 & 4.26 & & 0.35 & 0.11 & \\
\hline & & $X f$-Infected & $37.12^{*}$ & 14.68 & 0.017017 & $8.67^{* *}$ & 1.66 & 0.000483 \\
\hline \multirow[t]{4}{*}{$9621-94$} & 1 & Control & 1.00 & 0.00 & & 1.00 & 0.00 & \\
\hline & & $X f$-Infected & $2.22^{* *}$ & 0.42 & 0.003532 & $0.40^{* *}$ & 0.10 & 0.000203 \\
\hline & 6 & Control & 1.56 & 0.43 & & 0.60 & 0.20 & \\
\hline & & $X f$-Infected & 1.42 & 0.41 & 0.354589 & $0.23^{*}$ & 0.02 & 0.017818 \\
\hline
\end{tabular}

** Significant level at $\mathrm{P}<0.01$; Significant level at $\mathrm{P}<0.05$.

\section{Determination of candidate 3' termini of grape CYP736B transcripts}

Since transcription termination involves polyadenylation, the 3'termini of CYP736B transcripts were cloned using 3'RACE method to determine termination and poly(A) signals of CYP736B. Several major cDNA bands with different intensities were obtained from leaf tissues of both PD- resistant and susceptible grapevines at week 1 and week 6 (Figure 4). To elucidate the nature of these major 3'RACE cDNA bands, we isolated and cloned each major 3'RACE cDNA. Sequence analysis revealed that there were three major polyadenylation sites, as predicted from the bioinformatics-aided polyadnylation analysis (Figure $2)$ : poly(A)1 $(++53$ to ++58 , AATAAT), poly $(\mathrm{A}) 2(++153$ to ++159 , AATTAAA), and poly $(\mathrm{A}) 3(++238$ to ++245 , AATAAA).

Based on results of 3'RACE cDNA display (Figure 4), it appears that Poly(A)1 was the major polyadenylation site utilized for $C Y P 736 B$ transcripts under all conditions tested, while Poly(A)2 and $\operatorname{Poly}(\mathrm{A}) 3$ were less frequently used as alternative sites and subject to change upon plant growth and $X f$ inoculation. To quantify relative levels of representative 3 'RACE cDNAs, usage frequency of CYP736B transcripts with Poly(A)2 was determined using Real-time PCR. In leaf tissues of PD- resistant plants after $X f$ inoculation, total usage frequency of Poly(A)2 site was increased 12.38-fold at week 1 ( $\mathrm{n}=3$, $\mathrm{p}$ $=0.000057)$ but decreased 2.75-fold at week $6(\mathrm{n}=3, \mathrm{p}=$ $0.005304)$ when compared to respective control plants. However, usage frequency of $\operatorname{Poly}(\mathrm{A}) 2$ in leaf tissues of susceptible plants was not significantly increased (1.28fold greater than control, $\mathrm{n}=3, \mathrm{p}=0.075134)$ upon $X f$ infection at week 1 , and at week 6 (1.12-fold greater than control, $\mathrm{n}=3, \mathrm{p}=0.414483$ ) (Table 5).

\section{Correlation among transcription initiation, pre-mRNA splicing and polyadenylation of CYP736B genes}

The objective of this study was to understand coordination of transcription initiation and termination of $C Y P 736 B$ and its impact on pre-mRNA splicing after $X f$ inoculation. First, we used a 5'UTR-defined long 3'RACE strategy to amplify full-length cDNAs of CYP736B transcripts with various $5^{\prime}$ and $3^{\prime}$ ends. Only two representa-

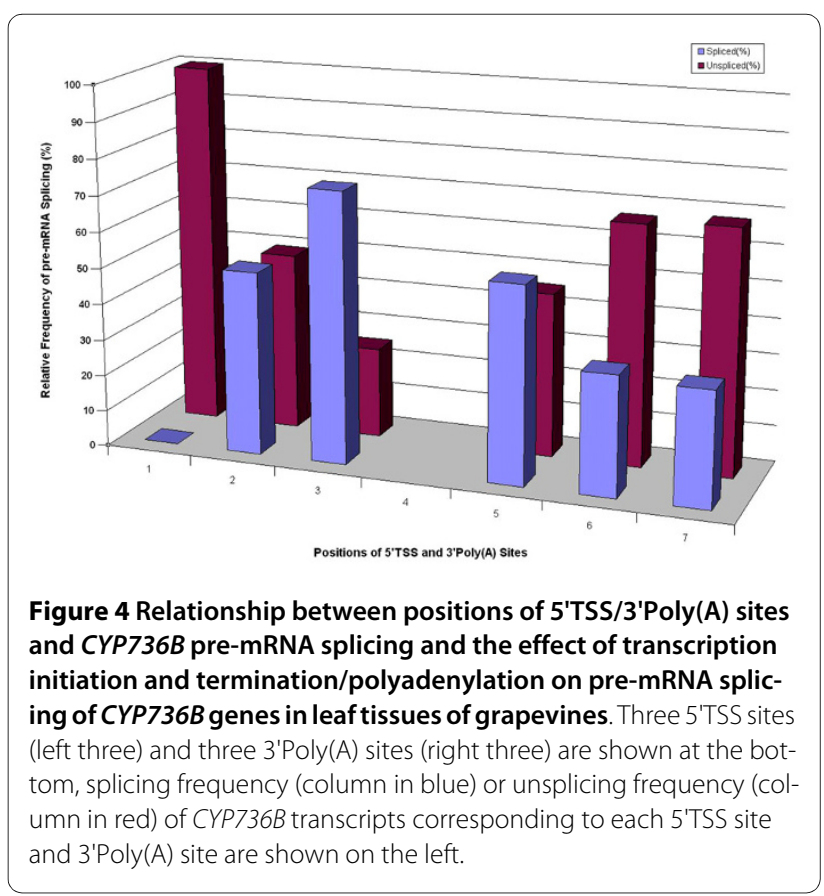


tive RNA samples were used in this test: PD-resistant and -susceptible leaf tissue harvested 6 weeks after $X f$ inoculation. The results revealed several distinguishable cDNA bands from each sample, as expected from $5^{\prime}$ RACE and 3' RACE data (Figures $3 \mathrm{a}$ and $3 \mathrm{~b}$ ). Based on the $5^{\prime}$ RACE and 3' RACE results and potential 5'TSS and 3'poly(A) site mapping results (Figures 2, Figure $3 \mathrm{a}$ and $3 \mathrm{~b}$ ), approximate size distributions of $C Y P 736 B$ transcripts with specific $5^{\prime}$ and 3 ' termini were estimated, and corresponding cDNA bands excised from the gel for cloning. Then, we designed three upstream primers located at the three different 5 'TSS regions: -300UF, -140UF, and -60UF (Table $1)$, and three downstream primers located at the three different 3'poly(A) regions: ++70UR, ++200UR, and ++260 UR (Table 1). Different combinations of these primers were used to amplify full-length cDNA sequences of CYP736B transcripts with specific 5'TSS and 3'poly(A) termini. Finally, relative abundance of each CYP736B transcript with specific initiation and termination/polyadenylation sites were quantified by a Real-time PCR with primers SYBR-P450F1 and SYBR-P450R1. As shown in Table 6, relative abundance of CYP736B transcript in leaf tissues of resistant plants with a specific initiation site at the -300 position in the TSS1-containing region was increased as the distance of each transcription termination/polyadenylation site increased from poly(A)1 to poly(A)3 ( $\mathrm{P}=0.0000 \sim 0.2968, \mathrm{R}^{2}=0.8940$ ). Relative abundance of $C Y P 736 B$ transcript with a specific transcription initiation site at the -140 position in the TSS2-containing region also was increased as the distance of each transcription termination/polyadenylation site increased from poly(A)1 to poly(A)2, but not poly $(\mathrm{A}) 3\left(\mathrm{P}=0.0010 \sim 0.2828, \mathrm{R}^{2}=0.8412\right)$. Relative abundance of $C Y P 736 B$ transcript with TSS2 sites was much higher than that with TSS1 sites in leaf tissues of PD- resistant plants. Relative abundance of CYP736B transcripts with the TSS1-containing region and TSS2containing region in leaf tissues of susceptible plants showed similar patterns of change $(\mathrm{P}=0.0000 \sim 0.4054$, $\mathrm{R}^{2}=0.8450$ within TSS1-containing region, $\mathrm{P}=0.0030 \sim$ $0.3039, \mathrm{R}^{2}=0.8936$ within TSS2-containing region, and $\mathrm{P}$ $=0.0002 \sim 0.0018$ between the TSS1-containing region and TSS2-containing region, respectively). However, abundance of each CYP736B transcript in susceptible plants was lower than in resistant plants $(\mathrm{P}=0.0015 \sim$ 0.0875 as compared within TSS1-containing region; and $\mathrm{P}=0.0082 \sim 0.3142$ as compared within TSS2-containing region, respectively).

We also cloned and sequenced representative cDNA sequences with different 5 'TSS and 3'poly(A) sites of CYP736B transcripts from PD-resistant and -susceptible leaf tissues 6 weeks after $X f$ inoculation. The genomic DNA and cDNA sequence alignment indicated that premRNA splicing patterns of CYP736B transcripts from PD-resistant and -susceptible leaf tissues 6 weeks after $X f$ inoculation remained the same as that in control plants even though various $C Y P 736 B$ transcripts contained different 5'TSS and 3'poly(A) sites (data not shown). Quantitative analysis of relative frequencies of each cDNA clone with or without intron sequence showed that the frequency of correct CYP736B pre-mRNA splicing was correlated with distance from transcription initiation sites to the translation start codon (ATG) or from transcription termination sites to the stop codon (TGA); the closer the distance, the higher the frequency of correctly spliced CYP736B pre-mRNA (Figure 3b). As distance from the

Table 5: Relative abundance of poly(A)2 site in the 3' termini of CYP736B Transcripts in leaf tissues of both PD-resistant (9621-67) and -susceptible (9621-94) plants after 1 and 6 weeks of inoculation with Xf

\begin{tabular}{|c|c|c|c|c|c|}
\hline \multirow[t]{2}{*}{ Genotype } & \multirow[t]{2}{*}{ Weeks } & \multirow[t]{2}{*}{ Treatment } & \multicolumn{3}{|c|}{ poly(A)2 Site } \\
\hline & & & $\begin{array}{l}\text { Average } \\
\text { (Fold diff }\end{array}$ & SD & t-test (p) \\
\hline \multirow[t]{4}{*}{$9621-67$} & 1 & Control & 1.49 & 0.39 & \\
\hline & & $X f$-Infected & $18.44^{* *}$ & 1.91 & 0.000057 \\
\hline & 6 & Control & 37.35 & 8.40 & \\
\hline & & $X f$-Infected & $13.6^{* *}$ & 3.48 & 0.005304 \\
\hline \multirow[t]{4}{*}{$9621-94$} & 1 & Control & 1.00 & 0.00 & \\
\hline & & $X f$-Infected & $1.28^{*}$ & 0.27 & 0.075134 \\
\hline & 6 & Control & 1.17 & 0.23 & \\
\hline & & $X f$-Infected & 1.12 & 0.26 & 0.414483 \\
\hline
\end{tabular}

** Significant level at $\mathrm{P}<0.01 ; *$ Significant level at $\mathrm{P}<0.05$. 
Table 6: Relative abundance of coordinated 5' TSS and 3' Poly(A) site usage for CYP736B gene transcription in leaf tissues of PD-resistant (9621-67) and -susceptible (9621-94) plants 6 weeks after Xf infection (fold difference)

\begin{tabular}{|c|c|c|c|c|c|c|c|c|c|}
\hline \multirow{2}{*}{$\frac{\text { Group }}{1}$} & \multirow{2}{*}{$\begin{array}{l}\text { Genotype } \\
9621-67\end{array}$} & \multirow{2}{*}{$\begin{array}{c}\text { From 5'TSS to } 3 \text { 'poly(A) } \\
(-300) \text { to }(++70)\end{array}$} & \multirow{2}{*}{\begin{tabular}{|c|} 
Mean \\
3.89
\end{tabular}} & \multirow{2}{*}{$\begin{array}{c}\text { SD } \\
0.77\end{array}$} & \multicolumn{2}{|c|}{ P19 } & \multicolumn{2}{|c|}{ P2ף } & \multirow[t]{2}{*}{$R^{2} \S$} \\
\hline & & & & & & & 0.0001 & 0.0015 & \\
\hline & & $(-300)$ to $(++200)$ & $6.91 *$ & 1.77 & 0.0270 & & 0.0003 & 0.0209 & \\
\hline & & $(-300)$ to $(++260)$ & $26.81^{* *}$ & 2.73 & 0.0001 & 0.0002 & 0.0003 & 0.0384 & 0.8940 \\
\hline \multirow[t]{3}{*}{ ॥ } & $9621-67$ & $(-140)$ to $(++70)$ & 64.77 & 2.14 & & & & 0.0082 & \\
\hline & & $(-140)$ to $(++200)$ & 77.24 & 11.99 & 0.0750 & & & 0.3142 & \\
\hline & & $(-140)$ to $(++260)$ & $166.21^{* *}$ & 24.65 & 0.0013 & 0.0025 & & 0.3017 & 0.8412 \\
\hline \multirow[t]{3}{*}{ III } & $9621-94$ & $(-300)$ to $(++70)$ & 1.00 & 0.00 & & & 0.0002 & & \\
\hline & & $(-300)$ to $(++200)$ & 2.68 & 1.74 & 0.0850 & & 0.0018 & & \\
\hline & & $(-300)$ to $(++260)$ & $20.34^{* *}$ & 3.86 & 0.0001 & 0.0010 & 0.0010 & & 0.8450 \\
\hline \multirow[t]{3}{*}{ IV } & $9621-94$ & $(-140)$ to $(++70)$ & 46.91 & 7.47 & & & & & \\
\hline & & $(-140)$ to $(++200)$ & $85.16^{*}$ & 23.31 & 0.0270 & & & & \\
\hline & & $(-140)$ to $(++260)$ & $153.03^{* *}$ & 32.17 & 0.0031 & 0.0208 & & & 0.8936 \\
\hline
\end{tabular}

I Student T-Test: P1 (within group) indicates the significance between two 5'TSS-3'Poly(A) types of transcripts within same assay group; P2 (between groups) indicates the significance between two 5'TSS-3'Poly(A) types of transcripts between groups.

$\S R^{2}$ shows correlation efficiency between each group of transcripts with fixed 5'TSS and various lengths of 3'-Poly $(A)$ ends and their relative abundance (fold difference) within each assay group.

${ }^{*}$ Significant level at $\mathrm{P}<0.01$; ${ }^{*}$ significant level at $\mathrm{P}<0.0$

poly(A)-containing region to the stop codon (TGA) increased, frequency of the spliced $C Y P 736 B$ RNA decreased. Statistical analysis showed that correlation of 5 'UTRs to mRNA splicing was as high as $\mathrm{R}^{2}=0.8302$ in resistant plants and $\mathrm{R}^{2}=0.9808$ in susceptible plants. The correlation efficiency of 3'UTRs to mRNA splicing was as high as $R^{2}=0.8922$ in resistant plants and $R^{2}=0.8678$ in susceptible plants.

\section{Discussion CYP736B expression is regulated by $\mathrm{Xf}$ infection and development}

Cytochrome P450 monooxygenase genes encode for a superfamily of enzymes in plants that seem to be involved in response to abiotic and biotic stresses [8,15]. Although several P450 genes play crucial roles in biosynthesis of a variety of endogenous lipophilic and antioxidative compounds, little is known about cytochrome P450 monooxygenase gene induction and regulation in response to pathogens. A previous study using cDNA microarray screening revealed that expression of several cytochrome P450 monooxygenase genes was tightly regulated during growth and development of grapevines in response to $X$. fastidiosa infection [unpublished data]. The current study identified a cluster of three cytochrome P450 monooxygenase genes (CYP736A, CYP736B, and CYP736C) that are organized as tandem repeats and flanked upstream with a RE-LTR sequence on chromosome 7 . This organization is likely the result of gene duplication [16-18]. We found that $C Y P 736 B$ was expressed at very low levels in stem tissues but at higher levels in leaf tissues of both PDresistant and -susceptible grapevines with or without $X f$ infection. While the level of CYP736B expression was quite different between leaf and stem tissues, patterns of gene expression in leaf and stem tissues were similar in both PD- resistant and susceptible grapevines. Differential expression in response to $X f$ infection between genotypes suggested that $C Y P 736 B$ may be involved in the host response to $X f$ infection. It is known that the relative density of $X f$ populations in stem tissues are much lower in PD-resistant compared to -susceptible grapevines [10]. This phenomenon may indicate that defense response genes, such as cytochrome P450 monooxygenase genes, may contribute to resistance against $X f$ infection in PDresistant grapevines. In fact, a wide range of cytochrome P450 monooxygenases mediate biosynthesis of lignins, terpenes, alkaloids, and a variety of other secondary compounds. Various biochemical pathways are involved in this process: the DIMBOA biosynthesis pathway that is initiated in response to wounding and naphthalic anhydride treatment [4]; the camalexin biosynthesis pathway that is coordinately induced and strictly localized to the site of pathogen infection [19], and the lignin biosynthesis pathway that is induced to ward off passive microbial and fungal invaders or to lignify tissues to limit extent of damage caused by active invaders [20]. Cytochrome P450 monooxygenases have other functions, including versatile biocatalytic reactions that mediate primary detoxifi- 
cation of natural and synthetic toxins [20,11,21]. However, relationships between these biochemical pathways and genes regulating disease resistance in plants are largely unknown.

In this study, transcription and pre-mRNA splicing patterns of CYP736B changed differently, depending on growth stage and $X f$ infection status. Induced expression levels of CYP736B were correlated positively with resistance and negatively with susceptibility in both stem and leaf tissues 6 weeks post-inoculation. These results support the conclusion that $C Y P 736 B$ is involved in the defense response against $X f$ infection in grapevines. We further demonstrated that expression of CYP736B was post-transcriptionally regulated via pre-mRNA splicing. The very low frequency of unspliced $C Y P 736 B$ transcripts in leaf tissues of PD-resistant grapevines and the very high frequency of unspliced $C Y P 736 B$ transcripts in leaf tissues of PD- susceptible grapevines (especially at 6 weeks post- $X f$ inoculation) may reveal an important aspect of the grapevine $X f$ interaction; correctly spliced CYP736B transcripts would be functional in PD-resistant grapevines, whereas unspliced $C Y P 736 B$ transcripts would not be functional in PD- susceptible grapevines. Differences in CYP736B expression levels between stems and leaves of grapevines would suggest that the levels of monooxygenase biosynthesis also vary. It seems that CYP736B expression involves dynamic regulatory mechanisms at both transcription initiation and the post-transcription modification levels via a developmentaldependent splicing pathway in PD- resistant grapevines. This result provides the first evidence that $C Y P 736 B$ is involved in the defense response at a specific stage of pathogenesis in grapevines.

\section{Multiple transcription initiations contribute to the regulation of CYP736B gene expression}

Transcriptional initiation of mRNAs is preceded by formation of a pre-initiation complex in eukaryotic cells. Diverse transcriptional initiation sites have been discovered by large scale mapping of mRNA start sites in the human genome [22]. Use of alternative transcription initiation sites is not uncommon in many animal and plant species [23,24]. Utilization of multiple transcription initiation sites may contribute to genetic flexibility in which expression may be temporally and spatially regulated. Furthermore, expression may be affected post-transcriptionally as demonstrated by differential expression and subcellular targeting of glutathione S-transferase F8 gene in Arabidopsis [25]. At present, regulatory mechanisms of cytochrome $\mathrm{P} 450$ monooxygenase genes in plants remain largely unknown. A previous study of cytochrome P450 expression and crosstalk in Arabidopsis revealed that most cytochrome $\mathrm{P} 450$ promoters contain the recognition sites MYB and MYC, an ACGT-core sequence, and
TGA and W-boxes for WRKY transcription factors [8]. Upon identification of genomic organization and expression patterns in grapevines, further determination of transcriptional initiation sites became a key step towards understanding transcriptional regulatory mechanisms. This study identified three major transcription start sites. Usage frequencies of each transcription start site varied depending on plant genotypes, developmental stages, tissues, and pathogen infection. Transcription start sites TSS2 and TSS3 were the major targets of transcriptional regulation during grapevine growth and development. Our study revealed that two TATA boxes, one P-box and one I-box were located at the far upstream region of CYP736B transcripts, whereas two CAAT boxes and a Gbox were located at the TSS1-containing region, and one W-box was located at the TSS2-containing region. Previous studies indicated that TATA boxes are the most common regulatory elements found in promoters of eukaryotic genes because they are associated with basal transcription initiation by RNA polymerase II, especially with cis-acting elements that enhance or repress transcription [26]. I-box (core sequence GATAA) and P-box (core sequence TGTAAAG) were associated with light and $\mathrm{ABA}$ responsiveness in tobacco and Arabidopsis respectively [27,28]. CAAT-box and G-box (core sequence CACGTG) were associated with tissue-specific regulation and heat shock induction in pea $[29,30]$. The W-box (core sequence CTGACT) is probably involved in elicitor- and wounding- responsive transcription of defense genes in tobacco [31,32]. If these cis-elements located within each CYP736B transcript are involved in physical interaction of the transcript with corresponding transcription factors, variation in frequencies of each transcription initiation site could reflect differences in $C Y P 736 B$ regulatory mechanisms triggered by $X f$. If so, selective use of transcription initiation sites would play an important role in regulation of CYP736B expression in response to $X f$ infection.

\section{Polyadenylation sites determine transcriptional termination of CYP736B}

Transcriptional termination by RNA polymerase II is known to be controlled by various regulatory elements located in 3'UTRs. Termination of transcription requires a functional polyadenylation site and the addition of a 3' poly(A) tail by poly(A) polymerase immediately after transcription [33,34]. The 3 ' end processing machinery functions to select an optimal poly(A) site between the poly(A) signal and a U-rich downstream element [35]. The sequence of the poly(A) signal and the number of uridine residues are known to affect polyadenylation efficiency $[35,36]$. However, the poly(A) site does not follow a strict consensus [37], even though a GC dinucleotide functions less efficiently than CA in vitro [38]. 
The research presented here revealed multiple poly(A) signals and multiple polyadenylation sites at the 3 ' UTR of CYP736B transcripts in both PD-resistant and -susceptible grapevines. There were 1 to 3 major polyadenylation sites with $\mathrm{A}$ or $\mathrm{U}$ as the terminal acceptor for polyadenylation. This result suggests that $A$ and $U$ are targets by poly(A) polymerase to synthesize poly(A) tails of CYP736B transcripts. Although there are examples of polyadenylation sites located between the poly(A) signal and a potential U-rich downstream element, a poly(A) signal could determine the optimal cleavage sites for CYP736B pre-mRNA polyadenylation. One possibility could be that the poly(A) polymerase-centered polyadenylation complex functions within the branched 3'UTR structure of $C Y P 736 B$ transcripts with some degree of flexibility after co-activation by poly $(\mathrm{A})$ signals in grapevines. Given that total usage frequency of poly(A)2 and poly $(\mathrm{A}) 3$ sites changed differently between $\mathrm{PD}$ - resistant and susceptible grapevines after $X f$ inoculation, it is possible that bacterial virulence factors are involved directly or indirectly in modulation of CYP736B transcript polyadenylation in grapevines.

\section{Coordination of transcription initiation and polyadenylation play a role in CYP736B splicing}

Transcription initiation, capping, cleavage/polyadenylation and pre-mRNA splicing are complex processes and tightly coupled to RNA polymerase II transcription. Transcription by RNA polymerase II and pre-mRNA processing are coordinated within the nucleus [39]. In general, capping at the 5 ' ends minimizes mRNA degradation and most importantly permits interaction with ribosomes. The $3^{\prime}$ end is completed by the addition of a polyA tail, resulting in increased mRNA stability, and introns are removed at some steps during this process [39]. Bucheli et al. [40] found that the balanced competition of transcription factors with mRNA processing factors may promote recognition of proper polyadenylation sites while suppressing cryptic sites. Valencia et al. [41] suggested that a functional coupling is usually not essential for gene expression, but enhances the rate and/or efficiency of reactions that may serve to increase fidelity of gene expression in higher eukaryotes. Xin et al. [42] studied relationships between alternative promoters and premRNA splicing and found that transcripts from different alternative promoters tended to splice differently. In the study presented here, variation in 5 transcription initiation sites or 3 ' polyadenylation sites affected $C Y P 736 B$ splicing. The combination of different transcription initiation sites and different 3 ' polyadenylation sites determined efficiency of CYP736B splicing in both PDresistant and susceptible grapevines. For instance, transcription initiation from the TSS1-containing region always produced unspliced $C Y P 736 B$ RNAs in either PD- resistant or susceptible leaf tissues 6 weeks after $X f$ inoculation. As distance from the TSS-containing region to the start codon ATG decreased, frequency of spliced CYP736B RNA increased. Similarly, transcription termination at the poly(A)1 region of the 3'UTR always produced the highest frequency of spliced $C Y P 736 B$ RNAs. More importantly, frequency of correct $C Y P 736 B$ premRNA splicing was correlated with both transcription initiation and termination sites distant to translation start and stop codons. The closer the distance from transcription initiation site to translation start codon and the distance from poly(A) site to translation stop codon, the higher the frequency of correctly spliced CYP736B transcripts. These relationships seem to be determined by changes in free energy within both 5'UTR and 3'UTR sequence-confined $2 \mathrm{D}$ structure constraints. Thus, our study revealed that both transcription initiation and termination have significant effects not only on relative abundance of CYP736B transcripts, but also on premRNA splicing. Grapevine genotype $/ X f$ interactions and their effect on $C Y P 736 B$ expression could be regulated by selective usage of transcription initiation and polyadenylation sites. The detailed regulatory mechanism of how $X f$ infection and grapevine/bacterial interactions affect selection of transcription initiation sites, polyadenylation sites, and pre-mRNA splicing remains to be understood. This report provides evidence that the cytochrome P450 monooxygenase CYP736B gene is involved in defense response at a specific stage of $X f$ infection in grapevines; multiple transcription initiation and polyadenylation sites exist for $C Y P 736 B$ in grapevine; and coordinated and selective use of transcription initiation and polyadenylation sites play an important role in regulation of $C Y P 736 B$ expression during growth, development and response to $X f$ infection.

\section{Methods}

\section{Plant growth and treatment with $\mathrm{Xf}$}

The PD-resistant 9621-67 and -susceptible 9621-94 lines were selected from the 9621 population (D8909-15 ( $V$. rupestris 'A. de Serres $\times$ V. arizonica b42-26) $\times$ F8909-17 (V. rupestris 'A. de Serres' $\times$ V. arizonica/candicans b4317)) [11]. A total of sixty plants from each genotype were propagated and grown at 24 to $32^{\circ} \mathrm{C}$ in a greenhouse with day lengths adjusted to 18 hours. After one month of growth, plants were cut back to two buds and re-grown for about 6 weeks before inoculation. Plants were inoculated with $10 \mu \mathrm{l}$ of the "Stag's Leap" strain of Xf $\left(1 \times 10^{8}\right.$ $\mathrm{cfu} / \mathrm{ml})$ as treatment groups or inoculated with $10 \mu \mathrm{l}$ of $X f$-free PW3 liquid media as control groups on the stem $10 \mathrm{~cm}$ above the pot surface following the procedure of Krivanek et al [10]. Each experimental unit consisted of three plants and was repeated three times in both treatment groups at each sampling date. Plants were arranged 
in a completely randomized design on greenhouse benches.

\section{Sample collection and evaluation}

Leaf and stem tissues of three plants per treatment were collected at week 1, 6 and 10 after inoculation with or without $X f$, respectively. Collected tissues were immediately placed in liquid nitrogen and stored at $-80^{\circ} \mathrm{C}$ until use. Symptoms were recorded as they appeared over a 12 week period on a separate set of 3 inoculated and 3 noninoculated plants for each genotype grown under the same conditions.

\section{Gene identification and primer design}

Based on the previous report [14], a genomic DNA sequence coding for a specific cytochrome P450 gene was identified from a grape genomic database (GenBank Accessions: $\quad$ AM475392.1, CAAP02000243.1, CAAP02005006.1) using the BLAST http://www. ncbi.nlm.nih.gov/ and FGENESH http://www.softberry.com/berry.phtml programs. A pair of primers, P450F1 and P450R1 (Table 1), was designed using Primer 3 Program http://biotools.umassmed.edu/bioapps/ primer3 www.cgi to clone this gene. Another pair of primers, P450F2 and P450R2, for quantitative Real-time PCR analysis of this cytochrome P450 gene expression, was designed using GeneFisher Program http:// bibiserv.techfak.uni-bielefeld.de/genefisher2/. Two pairs of primers, 5'UTRF1 and 5'UTRR1, 3'UTRF1 and 3'UTRR1 (Table 1), were designed using the Primer 3 Program to amplify and clone the 1,000 bp upstream and 600 bp downstream of the cytochrome P450 gene, respectively (Table 1).

\section{Total RNA isolation, CDNA synthesis and RT-PCR analysis of gene expression}

Total RNA was isolated using Trizol RNA Isolation Kit (Invitrogen, Carlsbad, CA). First strand cDNA was synthesized using oligo $(\mathrm{dT})_{20}$ primers with the cDNA Synthesis Kit (Invitrogen, Carlsbad, CA). RT-PCR analysis of gene expression was completed in a $25 \mu \mathrm{l}$ of reaction that consisted of $1 \times$ reaction buffer (with $1.5 \mathrm{mM} \mathrm{MgCl}_{2}$ ), 2 mM dNTPs, $100 \mathrm{ng}$ of cDNA template, $40 \mathrm{ng}$ of primers, and $0.2 \mu \mathrm{l}$ of Ampli Taq Gold DNA polymerase $(5 \mathrm{U} / \mu \mathrm{l})$ (Applied Biosystems, Foster City, CA). The RT-PCR program consisted of preheating at $94^{\circ} \mathrm{C}$ for $5 \mathrm{~min}, 30$ cycles of $94^{\circ} \mathrm{C}$ for $30 \mathrm{sec}, 55^{\circ} \mathrm{C}$ for $30 \mathrm{sec}$, and $72^{\circ} \mathrm{C}$ for $3 \mathrm{~min}$ followed by a $72^{\circ} \mathrm{C}$ extension for $10 \mathrm{~min}$. RT-PCR products were analyzed on a $1.2 \%$ of agarose gel in $1 \times$ TBE buffer with ethidium bromide staining. Real-time quantitative PCR analysis of gene expression was completed in a $25 \mu \mathrm{l}$ of reaction that consisted of $1 \times$ SYBR Green PCR Master Mix (Applied Biosystems, Foster City, CA), $100 \mathrm{ng}$ of template cDNA and $0.3 \mu \mathrm{M}$ of each primers SYBR-
P450F1 and SYBR-P450R1 (Table 1). The Real-time quantitative PCR was performed on the Bio-Rad iQ5 Multicolor Real-time PCR Detection System (Bio-Rad, Hercules, CA) with the PCR program of $95^{\circ} \mathrm{C} 10 \mathrm{~min}, 40$ cycles of $95^{\circ} \mathrm{C} 10 \mathrm{sec}$ and $60^{\circ} \mathrm{C} 1 \mathrm{~min}$, The Real-time PCR results were analyzed using a PCR product conversion and accumulation law-based delta Ct method [43,44]. The same Real-time quantitative PCR also was used for quantitative analysis of pre-mRNA splicing with a pair of primers (SYBR-P450F2 and SYBR-P450R2) under the same experimental and analytic conditions (Table 1).

\section{Northern blot and hybridization}

The Northern Max Formaldehyde-Based System for Northern Blots (Ambion, Texas) was used in this study according to the manufacturer's instruction. A full-length cDNA of grape cytochrome P450 monooxygenase gene CYP736B was labeled with biotin-dUTP at room temperature and used as probe for hybridization at $42^{\circ} \mathrm{C}$ for 18 hrs. Hybridization signals were detected using the BrightStar BioDetect Nonisotopic Detection Kit (Ambion, Texas).

\section{5'RACE and 3'RACE Analyses}

Determination of $5^{\prime}$ upstream transcription start regions and 3' poly(A) termination signal regions were done with the 5'RACE and 3'RACE Kits (Invitrogen, Carlsbad, CA). The two gene specific primers used for upstream $5^{\prime} \mathrm{RACE}$ cDNA cloning were P450-5'RACE GSP2 and P4505 'RACE GSP3 (Table 1). The two gene specific primers used for downstream 3'RACE cDNA cloning were P4503'RACE GSP1 and P450-3'RACE GSP2 (Table 1). Further quantitative measurements of the major 5'RACE and 3'RACE cDNAs were done using Real-time PCR analysis with primers SYBR-P450B 5'UTRF1 and SYBR-P450B 5'UTRR1, and SYBR-P450B 3'UTRF1 and SYBR-P450B 3'UTRR1, respectively, as described above (Table 1).

\section{Primer Extension Analysis}

Two gene specific primers, P450-5'RACE GSP3 for 5' primer extension analysis and P450-3'RACE GSP2 for 3'primer extension analysis, were designed to determine upstream transcriptional initiation regions and downstream transcriptional termination regions of grape P450B transcripts, respectively (Table 1). Total RNAbased or the 5'RACE and 3'RACE cDNA-based primer extension was completed in a $25 \mu \mathrm{l}$ reaction using a ThermoScript RT-PCR Kit (Invitrogen, Carlsbad, CA) according to the manufacturer's protocol. Primer extension products were separated in a $4 \%$ NuSieve $3: 1$ Agarose gel (Lonza Rockland, Inc., Rockland, ME), transferred to a Nylon membrane, and detected by the BrightStar BioDetect Nonisotopic Detection Kit (Ambion, Texas). 


\section{Quantification and cloning of representative full-length CDNA}

To determine relationships among different transcription initiation sites, pre-mRNA splicing, and polyadenylation signals, a modified 5'UTR-defined long 3'RACE method was designed in combination of the representative specific 5'UTR primers with the standard 3'RACE technology (Invitrogen, Carlsbad, CA). These specific 5'UTR primers were -300UF, -140UF, and -60UF (Table 1). The 5'UTR-defined long 3'RACE cDNA products were electrophoresed in a $4 \%$ agarose gel with TBE Buffer. Similarly, three representative specific 3'UTR reverse primers also were designed from the standard 3'RACE sequences: ++70 UR, ++200 UR, and ++260 UR (Table 1). The PCR system consisted of $1 \times$ LA Polymerase Buffer (with 1.5 $\mathrm{mM} \mathrm{MgCl} 2$ ), 2 mM dNTPs, 100 ng of cDNA template, 40 ng of primers, and $0.125 \mu \mathrm{l}$ of TAKARA Taq polymerase $(1 \mathrm{U} / \mu \mathrm{l})$ in a $25 \mu \mathrm{l}$ reaction. The PCR program consisted of preheating at $98^{\circ} \mathrm{C}$ for $10 \mathrm{sec}, 30$ cycles of $98^{\circ} \mathrm{C}$ for $10 \mathrm{sec}$, $55^{\circ} \mathrm{C}$ for $30 \mathrm{sec}$, and $72^{\circ} \mathrm{C}$ for $5 \mathrm{~min}$, and post-PCR extension at $72^{\circ} \mathrm{C}$ for $10 \mathrm{~min}$. The relative abundance of each specific 5'UTR and 3'UTR primer-defined P450 transcript was measured using Real-time Quantitative PCR as described above.

\section{DNA Cloning and Sequencing}

Genomic DNA, cDNA and RT-PCR product bands were excised from agarose gels, purified with the PCR Gel DNA Purification Kit (Invitrogen, Carlsbad, CA), and cloned into pGEM-T easy vector (Promega, Madison, WI). Cloned DNA fragments were sequenced with M13F, M13R and a pair of internal $\mathrm{P} 450$ primers, $\mathrm{P} 450 \mathrm{~F} 3$ and P450R3 (Table 1), using BigDye Terminator V3.1 Sequencing and Clean-Up Kits (Applied Biosystems, Foster City, CA).

\section{5'- and 3'-UTR DNA cis-acting regulatory element analysis}

A PLACE database http://www.dna.affrc.go.jp/PLACE/ signalscan.html was scanned to search key cis-acting regulatory elements located at the 5'- and 3'-UTRs of grape P450 genes. A PromScan program was used for grape P450 gene promoter analysis http://molbiol-tools.ca/ promscan/.

\section{Protein Block analysis}

The amino acid sequences of in silico translated P450 proteins were subjected to protein block analysis using the on-line program http://blocks.fhcrc.org/blocks/ blocks search.html.

\section{Statistical Analysis}

Gene expression experiments in this study were repeated three times with three plants of each genotype at each time of sample collection. The statistic significance of experimental variation was calculated using ANOVA at confidence levels of 99\% $(p<0.01)$ and 95\% $(p<0.05)$. The Student T-test was used to analyze significance between treatments for gene expression at the same confidence levels of $99 \%(p<0.01)$ and $95 \%(p<0.05)$.

\section{Authors' contributions}

DC, HL, YT and AW designed and conducted research experiments. DC was involved most expression analyses and the manuscript preparation. $H L$, AW, EC and DS were involved in organization of the work, writing and editing of the manuscript. HL was PI and initiator of the project. All authors took part in drafting, reviewing and approval of the final manuscript.

\section{Acknowledgements}

We gratefully acknowledge financial support from the California Department of Food and Agriculture's Pierce's Disease and Glassy-winged Sharpshooter Board and USDA, Agricultural Research Service.

\section{Author Details}

1San Joaquin Valley Agricultural Science Center, USDA-ARS 9611 South Riverbend Avenue, Parlier, CA 93648, USA, 2Department of Biology, California State University, Fresno, CA 93740, USA, 3 Department of Viticulture and Enology, University of California, Davis, CA 95616, USA and ${ }^{4}$ Department of Food sciences, Ehime Women's College, Uwajima, Ehime, 798-0025 Japan

Received: 27 October 2009 Accepted: 1 July 2010

Published: 1 July 2010

\section{References}

1. Isin EM, Guengerich FP: Complex reactions catalyzed by cytochrome P450 enzymes. Biochimica Biophysica Acta 2007, 1770:314-329.

2. Chou WM, Kutchan T: Enzymatic oxidation in the biosynthesis of complex alkaloids. Plant J 1998, 15:289-300.

3. Durst F, O'Keefe DP: Plant cytochrome P450: an overview. Drug Metabol Drug Interact 1995, 12:171-187

4. Persans MW, Wang J, Schuler M: Characterization of maize cytochrome P450 monooxygenases induced in response to safeners and bacterial pathogens. Plant Physiol 2001, 125:1126-1138.

5. Schuhegger R, Nafisi M, Mansourova M, Peterson BL, Olsen XE, Svatos A, Halkier BA, Glawischnig E: CYP71B15 (PAD3) catalyzes the final step in camalexin biosynthesis. Plant Physio/ 2006, 141:1248-1254

6. Glazebrook J: Contrasting mechanisms of defense against biotrophic and necrotrophic pathogens. Annu Rev Phytopathol 2005, 43:205-227.

7. Kliebenstein DJ, Rowe HC, Denby KJ: Secondary metabolites influence Arabidopsis/Botrytis interactions: variation in host production and pathogen sensitivity. Plant J 2005, 44:25-36

8. Narusaka Y, Narusaka M, Seki M, Umezawa T, Ishida J, Nakajima M, Enju A, Shinozaki K: Crosstalk in the responses to abiotic and biotic stresses in Arabidopsis: analysis of gene expression in cytochrome P450 gene superfamily by cDNA microarray. Plant Mol Biol 2004, 55:327-342.

9. Almeida RPP, Purcell AH: Transmission of Xylella fastidiosa to grapevines by Homalodisca coagulata (Hemiptera: Cicadellidae). J Econ Entomol 2003, 96:264-271.

10. Krivanek AF, Walker MA: Vitis resistance to Pierce's disease is characterized by differential Xylella fastidiosa populations in stems and leaves. Phytopathol 2005, 95:44-52.

11. Krivanek AF, Famula TR, Tenscher A, Walker MA: Inheritance of resistance to Xylella fastidiosa within a Vitis rupestris $\mathrm{x}$ Vitis arizonica hybrid population. Theor App/ Genetics 2005, 111:110-119.

12. Therne ET, Stevenson JF, Rost TL, Labavitch JM, Matthews MA: Pierce's disease symptoms: Comparison with symptoms of water deficit and the impact of water deficits. Am J Enol Vitic 2006, 57:1-11.

13. Krivanek AF, Riaz SN, Walker MA: Identification and molecular mapping of $P d R 1$, a primary resistance gene to Pierce's disease in Vitis. Theor App/Genetics 2006, 112:1125-1131.

14. Lin H, Doddapanneni H, Takahashi Y, Walker A: Comparative analysis of ESTs involved in grape responses to Xylella fastidiosa infection. BMC Plant Biol 2007, 7:8. doi:10.1186/1471-2229-7-8

15. Ehlting J, Sauveplane V, Olry A, Ginglinger J, Provart NJ, Werck-Reichhart $D$ : An extensive (co-)expression analysis tool for the cytochrome P450 superfamily in Arabidopsis thaliana. BMV Plant Biol 2008, 8:47. 
16. Cheng DW, Armstrong KC, Tinker N, Wight CP, He S, Lybaert A, Fedak G, Molnar SJ: Genetic and physical mapping of Lrk10-like receptor kinase sequences in hexaploid oat (Avena sativa L.). Genome 2002, 45:100-9.

17. Cheng DW, Shan $\mathrm{H}$, Armstrong KC: Modified expression and regulation of receptor kinase genes in response to rust pathogens in hexaploid oat. Physiologic and Molecular Plant Pathol 2002, 61:281-288.

18. Cheng DW, Armstrong KC, Drouion G, McElroy A, Fedak G, Molnar SD: Isolation and identification of Triticeae chromosome 1 receptor-like kinase genes in diploid, tetraploid and hexaploid species of the genus Avena. Genome 2003, 46:119-127.

19. Glawischnig E: The role of cytochrome P450 enzymes in the biosynthesis of camalexin. Biochem Soc Trans 2006, 34:1206-1028.

20. Berenbaum MR: Herbivores: Their Interactions with Secondary Plant Metabolites. Volume 1. Edited by: Rosenthal G, Berenbaum M. Academic Press, San Diego; 1991:221-249.

21. Werck-Reichhart D, Hehn A, Didierjean L: Cytochromes P450 for engineering herbicides tolerance. Trends Pharmaco/ Sci 2000, 5:1 16-123.

22. Suzuki Y, Taira H, Tsunoda T, Mizushima-Sugano J, Sese J, Hata H, Ota T, Isogai T, Tanaka T, Morishita S, et al:: Diverse transcriptional initiation revealed by fine, large-scale mapping of mRNA start sites. EMBO Rep 2001, 2:388-393.

23. Ayoubi TA, Van De Ven WJ: Regulation of gene expression by alternative promoters. FASEB J 1996, 10:453-460.

24. Kuhn $\mathrm{K}$, Weihe B, Borner T: Multiple promoters are a common feature of mitochondrial genes in. Arabidopsis Nucleic Acid Res 2005, 33:337-346.

25. Thatcher LF, Carrie C, Andersson CR, Sivasithamparam K, Whelan J, Singh KB: Differential gene expression and subcellular targeting of Arabidopsis glutathione S-transferase F8 is achieved through alternative transcription start sites. J Biol Chem 2007, 282:28915-28928.

26. Bassett CL, Nickerson ML, Farrell RE, Harrison M: Multiple transcripts of a gene for a leucine-rich repeat receptor kinase from morning glory (Ipmoea nil) originate from different TATA boxes in a tissue-specific manner. Mol Genet Genom 2004, 271:752-760.

27. Martinez-Hernandez A, Lopez-Ochoa L, Arguello-Astorga G, HerreraEstrella L: Functional properties and regulatory complexity of a minimal RBCS light-responsive unit activated by phytochrome, cryptochrome and plastid signals. Plant Physiol 2002, 128:1223-1233.

28. Nakashima K, Fujita Y, Katsura K, Maruyama K, Narusaka Y, Seki M, Shinozaki K, Yamaguchi-Shinozaki K: Transcriptional regulation of ABI3and ABA-responsive genes including RD29B and RD29A in seeds, germinating embryos, seedlings of Arabidopsis. Plant Mol Biol 2006 60:51-68

29. Chandrasekharan MB, Bishop KJ, Hall TC: Module-specific regulation of the beta-phaseolin promoter during embryogenesis. Plant J 2003 33:853-866.

30. Shirsat A, Wilford N, Croy R, Boulter D: Sequences responsible for the tissue specific promoter activity of a pea legumin gene in tobacco. $\mathrm{Mol}$ Gen Genet 1989, 215:326-331.

31. Nishiuchi T, Shinshi H, Suzuki K: Rapid and transient activation of transcription of the ERF3 gene by wounding in tobacco leaves: Possible involvement of NtWRKYs and autorepression. J Biol Chem 2004, 279:55355-55361

32. Yamamoto S, Nakano T, Suzuki K, Shinshi H: Elicitor-induced activation of transcription via $\mathrm{W}$ box-related cis-acting elements from a basic chitinase gene by WRKY transcription factors in tobacco. Biochem Biophys Acta 2004, 1679:279-287.

33. Proudfoot NJ: How RNA polymerase II terminates transcription in higher eukaryotes. Trends Biochem Sci 1989, 14:105-110.

34. Wilusz CJ, Mormington M, Peltz SW: The cap-to-tail guide to mRNA turnover. Nature Rev 2001, 2:237-246.

35. Chou ZF, Chen F, Wilusz J: Sequence and position requirements for uridylate-rich downstream elements of polyadenylation signals. NuCl Acids Res 1994, 22:2525-2531.

36. Colgan DF, Manley JL: Mechanism and regulation of mRNA polyadenylation. Genes Dev 1997, 11:2755-2766.

37. Zhao J, Hyman L, Moore C: Formation of mRNA 3' ends in eukaryotes: mechanism, regulation, and interrelationships with other steps in mRNA synthesis. Microbio Mol Biol Rev 1999, 63:404-445

38. Chen F, MacDonald CC, Wilusz J: Cleavage site determinants in the mammalian polyadenylation signal. Nucl Acids Res 1995, 23:2614-2620.
39. Cramer P, Srebrow A, Kadener S, Werbajh S, de la Mata M, Melen G, Nogues G, Kornblihtt AR: Coordination between transcription and premRNA processing. FEBS Lett 2001, 498:179-182.

40. Bucheli ME, He X, Kaplan CD, Moore CL, Buratowski S: Polyadenylation site choice in yeast is affected by competition between $\mathrm{Npl} 3$ and polyadenylation factor CFI. RNA 2007, 3:1756-1764.

41. Valencia P, Dias AP, Reed R: Splicing promotes rapid and efficient mRNA export in mammalian cells. Proc Natl Acad Sci USA 2008, 105:3386-3391.

42. Xin $\mathrm{D}, \mathrm{Hu} \mathrm{L}$, Kong $\mathrm{X}$ : Alternative promoters influence alternative splicing at the genomic level. PLOS ONE 2008, 3:e2377.

43. Cheng DW: Transformation and accumulation laws of PCR amplification products. Hereditas (Beijing) 1991, 13:33-38

44. Bookout AL, Cummins CL, Mangelsdorf DJ, Pesola JM, Kramer MF: Highthroughput real-time quantitative reverse transcription PCR. Curr Proto Mol Biol 2006, Chapter 15(Unit 15.8):

doi: $10.1186 / 1471-2229-10-135$

Cite this article as: Cheng et al., Transcriptional regulation of the grape cytochrome P450 monooxygenase gene CYP736B expression in response to Xylella fastidiosa infection BMC Plant Biology 2010, 10:135

\section{Submit your next manuscript to BioMed Central and take full advantage of:}

- Convenient online submission

- Thorough peer review

- No space constraints or color figure charges

- Immediate publication on acceptance

- Inclusion in PubMed, CAS, Scopus and Google Scholar

- Research which is freely available for redistribution
C Biomed Central 